\title{
Effect of Transplant Age, Tobacco Cultivar, Acibenzolar-S-Methyl, and Imidacloprid on Tomato Spotted Wilt Infection in Flue-Cured Tobacco
}

\author{
C. Nischwitz, A. S. Csinos, S. W. Mullis, L. L. Hickman, K. L. Stevenson, and R. D. Gitaitis, Department of \\ Plant Pathology, University of Georgia, Coastal Plain Experiment Station, Tifton 31793-0748
}

\begin{abstract}
Nischwitz, C., Csinos, A. S., Mullis, S. W., Hickman, L. L., Stevenson, K. L., and Gitaitis, R. D. 2008. Effect of transplant age, tobacco cultivar, acibenzolar-S-methyl, and imidacloprid on tomato spotted wilt infection in flue-cured tobacco. Plant Dis. 92:1524-1528.

Tomato spotted wilt virus (TSWV) has become the most serious problem in flue-cured tobacco in Georgia and is a growing problem in other tobacco-growing areas in the United States. The effects of transplant age (6 to 10 weeks), tobacco cultivar (K-326 and NC-71), and preplant applications of acibenzolar-S-methyl (ASM) and the insecticide imidacloprid (IMD) were evaluated on levels of TSWV infection, number of symptomatic plants, and yield in field trials over 4 years. In all 4 years and in four of five trials, treatment of transplants with ASM and IMD resulted in fewer symptomatic plants, smaller areas under the disease progress curve (AUDPC), and higher yields compared with the nontreated controls. There were no consistent effects of transplant age or cultivar on number of symptomatic plants or systemic infections, AUDPC, or yield. Treatment of transplants with ASM and IMD can significantly reduce the number of symptomatic plants in the field and substantially increase yields and value per hectare.
\end{abstract}

Additional keywords: systemic acquired resistance

Tomato spotted wilt virus (TSWV; family: Bunyaviridae) remains a serious problem in flue-cured tobacco production in Georgia and other parts of the United States. Stand losses in recent years have averaged $30 \%$ across the state, with total losses in some fields. There are no commercially available TSWV-resistant cultivars and resistant transgenic tobacco lines that have the TSWV nucleoprotein gene are not accepted by the tobacco industry. Current management strategies may still result in high infection rates. Therefore, other management strategies need to be developed.

In many crops, acibenzolar- $S$-methyl (ASM) has been shown to induce resistance against bacterial, fungal, and viral plant pathogens as well as nematodes. ASM induced resistance in pepper to bacterial spot caused by Xanthomonas axonopodis pv. vesicatoria as early as 3 days after application (16) and significantly increased survival of pepper plants against Phytophthora root and crown rot (10). Studies on the effect of ASM on tomato spotted wilt incidence on tomato and tobacco showed a significant reduction in incidence in combination with other treat-

Corresponding author: C. Nischwitz

E-mail: cnisch@uga.edu

Accepted for publication 17 July 2008 .

doi:10.1094/PDIS-92-11-1524

(c) 2008 The American Phytopathological Society ments such as reflective mulches and insecticides (12) or with timing of application, such as when applied before transplanting $(4,11)$. Reproduction of the rootknot nematode (Meloidogyne javanica) and the reniform nematode (Rotylenchulus reniformis) was significantly reduced after pineapple plants (Ananas comosus) were treated with ASM (2).

Imidacloprid (IMD) is a neonicotinoid insecticide. It has both systemic and contact activity for the control of sucking insects, including thrips. Joost and Riley (6) found that the tobacco thrips (Frankliniella fusca) reduced probing time on plants treated with IMD and preferred to feed on nontreated plants. IMD acts on the insects in two ways, either killing them directly as a nerve toxin or indirectly when insects avoid feeding on treated plants and starve (13). In combination with ASM, it reduces TSWV incidence $(4,14)$.

Tobacco growers plant transplants with a range of different ages but prefer to grow older, 10-week-old transplants. Age of plants at the time of infection plays a significant role in the incidence of some viral infections. Sugar beet seedlings were more susceptible to infection with Beet curly top virus and losses were higher than when older plants were infected (19). Also, Lapidot (7) found that seedling age affected resistance of common bean cultivars to Tomato yellow leaf curl virus, with 14day-old plants being nearly $100 \%$ susceptible, whereas 26- and 12-day-old plants had only 34 and $40 \%$ infection, respectively. Mandal et al. (9) found that age of tobacco plants at the time of inoculation with TSWV in the greenhouse had an effect on the development of local lesions and systemic infection. The 14-week-old plants had fewer local lesions per plant and fewer plants developed local lesions compared with 6- or 10-week-old plants. Systemic infections were significantly reduced in the 14-week-old plants compared with the 6- or 10-week-old plants. The objectives of this study were to determine if transplant age and preplant applications of ASM and IMD influence TSWV incidence, yield, and crop value in flue-cured tobacco.

\section{MATERIALS AND METHODS}

2002 trial. In 2002, tobacco cv. NC-71 was grown in 242-cell float trays and seeded 2 weeks apart, such that transplants of three different ages were produced in greenhouses at the University of Georgia Coastal Plain Experiment Station. Cv. NC71 was used because K-326, the cultivar preferred by growers at that time, was not available at planting time. At transplanting, the seedlings were 6,8 , and 10 weeks old The 10-week-old transplants (10-WOT) had been clipped several times, the 8-WOT were clipped fewer times to manage plant size, and the 6-WOT were clipped at least once. Four days before transplanting, both ASM (Actigard $50 \mathrm{WG}$, at $2 \mathrm{~g}$ a.i. per 7,000 plants; Syngenta Crop Protection, Greensboro, NC) and IMD (Admire 2F, at 7.1 g a.i. per 1,000 plants; Bayer CropScience, Kansas City, MO) were sprayed onto all treatments (except for the control plants) and washed into the root system. Transplants were planted in the field on 29 March at the University of Georgia's Bowen Farm in Tifton. The plot size was a single row $10.7 \mathrm{~m}$ long and the spacing between plants was $45.7 \mathrm{~cm}$. After transplanting, the recommended management protocol for tobacco production in Georgia was followed with the exception that no insecticides lethal to thrips were applied (1).

2003, 2004, and 2006 trials. In 2003, 2004 , and 2006, two cultivars, K-326 and NC-71, and K-326 transformed with the $\mathrm{N}$-gene of TSWV (courtesy of Dr. Nicholson at North Carolina State University) were grown in 242-cell float trays in the greenhouse. Cv. NC-71 was included in these trials to reflect recent trends in cultivar preference among the growers. The transgenic line was included as a nonsus- 
ceptible standard to determine the yield potential in each year of uninfected plants. Seed were sown on different dates in order to produce 6-WOT and 10-WOT of each cultivar at time of planting. All transplants were planted in the field on the same day. Before transplanting, the 10-WOT were clipped several times to manage growth in preparation for transplanting and the 6WOT were clipped at least once. In 2003 and 2004, 3 days prior to transplanting, all treatments except for the controls and the transgenic line were treated with ASM (Actigard $50 \mathrm{WG}$ at $2 \mathrm{~g}$ a.i. per 7,000 plants) and IMD (Admire $2 \mathrm{~F}$ at $7.1 \mathrm{~g}$ a.i. per 1,000 plants). In 2006, all the transplants except for the controls and the transgenic line were sprayed with ASM (Actigard 50 WG at $2 \mathrm{~g}$ a.i. per 7,000 plants) and IMD (Admire Pro 4.6 at $16.5 \mathrm{~g}$ a.i. per 1,000 plants). The plants were overhead irrigated to remove the chemicals from the foliage and wash them into the soil. The higher rate of IMD was used because the plots were in a location with high TSWV incidence. The plots were established at the University of Georgia's Bowen Farm in Tifton. The plot size in 2003 was a single row $11.3 \mathrm{~m}$ long and the spacing between plants was $45.7 \mathrm{~cm}$. In 2004, the plot size was four rows $11.3 \mathrm{~m}$ long and the spacing between plants was $56 \mathrm{~cm}$. The plants in the two middle rows were used for data collection. The plots in 2006 were double rows $11.3 \mathrm{~m}$ long and the plant spacing within the row was 56 $\mathrm{cm}$. Post-transplant management protocols were as described for the 2002 trial. In 2003, two trials were planted, on 19 March and 15 April. They will be referred to in the rest of the article as the 2003 trial (early planting) and 2003 trial (late planting), respectively. In 2004, the transplants were planted on 23 March and in 2006 on 7 April.

Treatments and experimental design. In the 2002 trial, the experiment was designed as a randomized complete block with a three-by-two factorial treatment arrangement and five replications of each treatment combination. Main treatment factors were transplant age (6-, 8-, or 10WOT) and chemical treatment (no treatment or ASM + IMD). In the 2003 (early planting), 2003 (late planting), 2004, and 2006 trials, the experiments were designed as randomized complete blocks with a two-by-two-by-two factorial arrangement of treatments and five replications of each treatment combination. Main treatment factors were cultivar (K-326 or NC-71), transplant age (6- or 10- WOT), and chemical treatment (no treatment or ASM + IMD). In each year except 2002, five replicate plots were planted with the transgenic K-326 cultivar as a nonsusceptible standard to demonstrate yield potential of uninfected tobacco in each year. The transgenic plants were not treated with ASM or IMD.
Data collection. Stand counts were made every 2 weeks starting 2 weeks after transplanting for the 2002 trial; once a week starting 1 week after transplanting and ending after the final harvest for the 2003 (early planting), 2003 (late planting), and 2004 trials; and starting 1 week after transplanting and ending at topping for the 2006 trial. Plants were topped about 80 days after planting by removing the blooms and the top two or three leaves according to grower standards. All plants were visually assessed each week for symptoms, and plants showing symptoms of TSWV were flagged in the field and recorded as a percentage of the total plant stand. The area under the disease progress curve (AUDPC) was calculated for each plot based on the weekly assessments of percentage symptomatic plants. Leaves were sequentially harvested and weighed three times to determine the total yield. Harvest took place in July and the first week of August depending on weather conditions. Yield was recorded as total dry weight, which was calculated by multiplying the green weight by 0.2 (3). Revenue differences between treated and nontreated transplants were calculated based on estimates for 2007 prices for contract tobacco (US\$3.31/kg).

The percentage of TSWV-infected plants in each plot was determined at harvest based on a double-antibody sandwich enzyme-linked immunosorbent assay (DAS-ELISA) specific for TSWV (Agdia Inc., Elkhart, IN). After the last harvest, root samples were obtained from 10 randomly selected plants per plot for each of the five replications. Sap was extracted from approximately $200 \mathrm{mg}$ of fresh root tissue and stored in $1 \mathrm{ml}$ of extraction buffer (for 1 liter of buffer: 1 packet of $20 \times$ phosphate-buffered saline-Tween concentrate [Agdia Inc.], $1.3 \mathrm{~g}$ of sodium sulfite (anhydrous), $20 \mathrm{~g}$ of polyvinylpyrrolidone [MW 24,000 to 40,000], $2 \mathrm{~g}$ of chicken egg albumin, $20 \mathrm{~g}$ of Tween-20, and 1,000 $\mathrm{ml}$ of double-distilled water; $\mathrm{pH}$ 7.4). The extract was then used in the ELISA following the manufacturer's instructions.

Data analysis. The data were analyzed using PROC MIXED in SAS (version 9.1; SAS Institute, Cary, NC). ELISA tests of transgenic K-326 plants were always positive, as expected, due to the incorporation of the TSWV coat protein gene in the tobacco genome. Positive ELISA tests are not a reflection of virus infection in transgenic tobacco (18); therefore, the data were not included in the analysis. The percentage of symptomatic plants and percentage of systemic infections were converted to proportions and arcsinesquare-root transformed prior to analysis. Main fixed effects of transplant age, cultivar, and chemical treatment and their interactions on percent symptomatic plants, percent systemic infection, yield, and AUDPC were evaluated. When interactions between fixed-effect treatment factors were significant, contrast statements were used to determine significant differences among least squares treatment means. The data presented for percent symptomatic plants, percent systemic infection, AUDPC, and yield are calculated based on the main treatment effects. Therefore, different values for the same variable can be found in tables for an individual year.

\section{RESULTS}

2002 trial. The percentage of symptomatic plants was significantly lower $(P=$ $0.04)$ in the transplants treated with ASM and IMD than in the nontreated transplants (Table 1). The AUDPC values also were significantly lower in transplants treated with ASM and IMD compared with the nontreated transplants. Older transplants

Table 1. Effect of acibenzolar-S-methyl (ASM) and imidacloprid (IMD) treatment of NC-71 tobacco transplants on development of Tomato spotted wilt virus symptoms, systemic infection, and yield in the 2002 trial $^{\mathrm{v}}$

\begin{tabular}{|c|c|c|c|c|}
\hline Treatment, age (weeks) ${ }^{w}$ & $\begin{array}{l}\text { Symptomatic } \\
\text { plants }(\%)^{x}\end{array}$ & AUDPC & $\begin{array}{c}\text { Systemic } \\
\text { infection }(\%)^{\mathrm{z}}\end{array}$ & $\begin{array}{l}\text { Yield (kg/ha } \\
\text { dry weight) }\end{array}$ \\
\hline \multicolumn{5}{|l|}{ ASM + IMD } \\
\hline 6 & 46 & 1,414 & 58 & 2,151 \\
\hline 8 & 36 & 1,191 & 42 & 2,381 \\
\hline 10 & 36 & 1,114 & 60 & 2,237 \\
\hline Mean & $39 \mathrm{a}$ & $1,240 \mathrm{a}$ & $53 \mathrm{a}$ & $2,256 \mathrm{a}$ \\
\hline \multicolumn{5}{|l|}{ None } \\
\hline 6 & 59 & 2,553 & 58 & 1,042 \\
\hline 8 & 48 & 1,819 & 62 & 1,492 \\
\hline 10 & 44 & 1,600 & 70 & 1,801 \\
\hline Mean & $50 \mathrm{~b}$ & $1,991 \mathrm{~b}$ & $63 \mathrm{a}$ & $1,445 \mathrm{~b}$ \\
\hline
\end{tabular}

${ }^{\mathrm{v}}$ Means within a column followed by the same letter were not significantly different $(\alpha=0.05)$ based on $F$ tests in SAS PROC MIXED.

${ }^{\mathrm{w}}$ Chemical treatment and transplant age.

$\mathrm{x}$ Values are means of five replications.

y AUDPC (area under the disease progress curve) based on weekly assessments of percentage of symptomatic plants in each of five replications.

${ }^{\mathrm{z}}$ Systemic infection was determined by enzyme-linked immunosorbent assay. Values are means of percentages of positives based on root samples of 10 randomly selected plants per plot for each of five replications. 
had fewer symptomatic plants and a lower AUDPC compared with the younger transplants but the differences were not statistically significant $(\alpha=0.05)$. There was no significant effect of chemical treatment or transplant age on the percentage of systemic infections. The yield of transplants treated with ASM and IMD was significantly higher than that of nontreated transplants (Table 1). Transplant age had no effect on yield. There was no interaction between transplant age and chemical treatment for any of the variables measured.

2003 (early planting) trial. There was a significant interaction between transplant age and chemical treatment on percentage of symptomatic plants and AUDPC but no interaction among cultivar, transplant age, and chemical treatment. Treatment of 6WOT with ASM and IMD resulted in significantly fewer symptomatic plants $(24 \%)$ compared with nontreated 6-WOT (39\%) but treatment of 10-WOT with ASM and IMD had no effect on the percentage of symptomatic plants (Table 2). Nontreated 6-WOT had a significantly higher percentage of symptomatic plants $(39 \%)$ than nontreated 10 -WOT $(21 \%)$ but there was no significant effect of transplant age or cultivar on the percentage of symptomatic plants for transplants treated with ASM and IMD. The 6-WOT treated with ASM and IMD had a significantly lower AUDPC than nontreated 6-WOT and 6-WOT nontreated transplants had a significantly higher AUDPC than nontreated 10-WOT. There were no significant interactions and no significant effect of chemical treatment, transplant age, or cultivar on the percentage of systemic infections (data not shown) or yield. The mean percentage of systemic infections for all treatments was $32 \%$. The mean yield of treated and nontreated 10 -WOT $(2,872 \mathrm{~kg} / \mathrm{ha}$ dry weight) was higher than for the 6-WOT

Table 2. Effects of acibenzolar- $S$-methyl (ASM) and imidacloprid (IMD) treatment of tobacco transplants on development of Tomato spotted wilt virus symptoms in the 2003 (early planting) trial ${ }^{\mathrm{v}}$

\begin{tabular}{lccc}
\hline Treatment, age (weeks) $^{\mathbf{w}}$ & \multicolumn{1}{c}{ Symptomatic plants (\%) } & AUDPC $^{\mathbf{y}}$ & Yield (kg/ha dry weight) $^{\mathbf{z}}$ \\
\hline ASM + IMD & & & \\
6 & $24 \mathrm{aA}$ & $720 \mathrm{aA}$ & $2,859 \mathrm{a}$ \\
10 & $25 \mathrm{aA}$ & $698 \mathrm{aA}$ & $2,846 \mathrm{a}$ \\
None & & & \\
6 & $39 \mathrm{bA}$ & $1,322 \mathrm{bA}$ & $2,526 \mathrm{a}$ \\
10 & $21 \mathrm{aB}$ & $657 \mathrm{aB}$ & $2,897 \mathrm{a}(3,334)$ \\
\hline
\end{tabular}

${ }^{v}$ Values are means of five replications of two cultivars (NC-71 and K-326). Means within a column followed by the same letter were not significantly $(\alpha=0.05)$ different based on $F$ tests in SAS PROC MIXED.

${ }^{\mathrm{w}}$ Chemical treatment and transplant age.

${ }^{x}$ Lowercase letters indicate differences between chemical treatments and uppercase letters indicate differences between transplant ages.

${ }^{y}$ AUDPC $=$ area under the disease progress curve, based on weekly assessments of percentage of symptomatic plants. Lowercase letters indicate differences between chemical treatments and uppercase letters indicate differences between transplant ages.

${ }^{\mathrm{z}}$ Value in parentheses is the yield of the nonsusceptible transgenic K-326.

Table 3. Effects of acibenzolar-S-methyl (ASM) and imidacloprid (IMD) treatment of tobacco transplants on the incidence of Tomato spotted wilt virus and yield in the 2003 (late planting), 2004 and 2006 trials $^{\mathrm{v}}$

\begin{tabular}{lcccl}
\hline Trial, treatment & $\begin{array}{c}\text { Symptomatic } \\
\text { plants (\%) }\end{array}$ & AUDPC $^{\mathbf{w}}$ & $\begin{array}{c}\text { Systemic infection } \\
(\%)^{\mathbf{x}}\end{array}$ & $\begin{array}{c}\text { Yield (kg/ha } \\
\text { dry weight) }\end{array}$ \\
\hline 2003 (late) & & & & \\
ASM + IMD & $12 \mathrm{a}$ & $365 \mathrm{a}$ & $24 \mathrm{a}$ & $3,039 \mathrm{a}$ \\
None & $34 \mathrm{~b}$ & $1,384 \mathrm{~b}$ & $40 \mathrm{~b}$ & $2,622 \mathrm{~b}(3,667)$ \\
2004 & $49 \mathrm{a}$ & $1,279 \mathrm{a}$ & $61 \mathrm{a}$ & $2,129 \mathrm{a}$ \\
ASM + IMD & $65 \mathrm{~b}$ & $2,150 \mathrm{~b}$ & $65 \mathrm{a}$ & $1,704 \mathrm{~b}(3,221)$ \\
None & & & & \\
2006 & $22 \mathrm{a}$ & $399 \mathrm{a}$ & $55 \mathrm{a}(37 \mathrm{a})^{\mathrm{z}}$ & $3,220 \mathrm{a}$ \\
ASM + IMD & $46 \mathrm{~b}$ & $1,156 \mathrm{~b}$ & $59 \mathrm{a}(62 \mathrm{~b})^{\mathrm{z}}$ & $2,516 \mathrm{~b}(3,052)$ \\
None &
\end{tabular}

${ }^{v}$ Values are means of five replications of two cultivars (NC-71 and $\left.\mathrm{K}-326\right)$ and two transplants ages (6-week-old transplants [6-WOT] and 10-WOT). Means within a column and year followed by the same letter were not significantly different $(\alpha=0.05)$ based on $F$ tests in SAS PROC MIXED.

${ }^{\mathrm{w}}$ AUDPC $=$ area under the disease progress curve, based on weekly assessments of percentage of symptomatic plants.

x Systemic infection was determined by enzyme-linked immunosorbent assay. For the 2003 (late) and 2004 trials, values are means of percentages of positives based on root samples of 10 randomly selected plants per plot for each of five replications of two cultivars (NC-71 and K-326) and two transplant ages (6-WOT and 10-WOT).

y Values in parentheses are mean yields for the nonsusceptible transgenic K-326.

${ }^{\mathrm{z}}$ Due to an interaction between chemical treatment and transplant age in the 2006 trial, the percent systemic infection was reported separately for 6-WOT and 10-WOT. Values shown are means of five replications of two cultivars (NC-71 and K-326) for 6-WOT and 10-WOT (in parentheses).
$(2,676 \mathrm{~kg} / \mathrm{ha}$ dry weight), but the difference was not statistically significant $(\alpha=$ 0.05). No symptoms of TSWV were observed in the transgenic K-326 plants. Yield of transgenic K-326 was the highest, with $3,334 \mathrm{~kg} / \mathrm{ha}$ dry weight.

2003 (late planting) trial. There were no significant interactions among cultivar, transplant age, and chemical treatment. Treatment with ASM and IMD significantly reduced the percentage of symptomatic plants, AUDPC, and the percentage of systemic infections and increased yield compared with the nontreated controls (Table 3). The AUDPC was significantly lower and the percentage of systemic infections significantly higher for NC-71 transplants than K-326 transplants, although there was no effect of cultivar on the percentage of symptomatic plants and yield (Table 4). No symptoms of TSWV were observed in the transgenic K-326 plants. Yield of transgenic K-326 was $3,667 \mathrm{~kg} / \mathrm{ha}$ dry weight. There was no effect of transplant age on the percent symptomatic plants, yield, percent systemic infection, or AUDPC (data not shown).

2004 trial. There were no significant interactions among cultivar, transplant age, and chemical treatment. Treatment with ASM and IMD resulted in significantly fewer symptomatic plants, lower AUDPC values, and higher yield compared with the nontreated control but had no effect on the percentage of systemic infections (Table 3). NC-71 transplants had a significantly lower percent symptomatic plants, AUDPC, percent systemic infections, and higher yield than K-326 (Table 4). Transplant age had no effect on the percent symptomatic plants, yield, AUDPC value, or percent systemic infection (data not shown). No symptoms of TSWV were observed in the transgenic K-326 plants. Yield of transgenic K-326 was $3,221 \mathrm{~kg} / \mathrm{ha}$ dry weight.

2006 trial. Treatment with ASM and IMD resulted in significantly fewer symptomatic plants and lower AUDPC values compared with the nontreated control (Table 3). Yields were significantly higher in transplants treated with ASM and IMD compared with nontreated controls (Table 3 ). The 10-WOT had a significantly smaller percentage of symptomatic plants, lower AUDPC, and higher yields than 6WOT (Table 5). Both cultivar and chemical treatment had significant effects on percentage of systemic infection. And, although there was no significant main effect of transplant age, there was a significant interaction between chemical treatment and transplant age on percentage of systemic infections. K-326 transplants had significantly more systemic infections (mean of $63 \%$ ) than NC-71 transplants (mean of 44\%). The 10-WOT treated with ASM and IMD had a significantly lower percentage of systemic infections than 
nontreated 10-WOT (mean of 37 versus $62 \%$, respectively) but there was no significant effect of chemical treatment on percent systemic infection in the 6-WOT, with means of 55 and $59 \%$ in treated and nontreated plants, respectively (Table 3 ). Cultivar had no effect on yield, percent symptomatic plants, or AUDPC (data not shown). Symptoms of TSWV were observed on $17 \%$ of transgenic K-326 plants and yield of transgenic K-326 was 3,052 $\mathrm{kg} / \mathrm{ha}$ dry weight. There was no interaction among cultivar, chemical treatment, and transplant age on any of the variables measured.

\section{DISCUSSION}

TSWV management is complicated because the virus must be vectored by thrips for infection to occur. Many factors affect the reproduction of both thrips and the virus, and these relationships are poorly understood. ASM is a plant activator and functions as an analog of the naturally occurring salicylic acid in the systemic acquired resistance (SAR) signal transduction pathway $(5,8,15)$. The signal transduction pathway leads to the activation of SAR genes that result in the production of pathogenesis-related proteins such as chitinases and $\beta$-1,3-glucanases (17) throughout the plant. The activation of SAR by ASM may affect both the infection process and the reproduction and movement of the virus in the plant. IMD affects feeding habits of thrips and operates primarily as a feeding deterrent on seedlings (6). The pretreatment with ASM and IMD reduced the percentage of symptomatic plants and increased yields in all 4 years. Yield increases ranged from 417 to $751 \mathrm{~kg} / \mathrm{ha}$ dry weight. Based on conservative 2007 estimates for contract prices for tobacco (US\$3.31/kg), the increased income potential associated with these yield increases is a substantial $\$ 1,380$ to $2,486 /$ ha. The cost of greenhouse application of ASM and IMD per hectare was approximately US\$140. The return for this investment was between US\$600 and $3,600 /$ ha, which could be the difference between a profit or a loss for a grower. In the 2006 trial, symptoms were observed on $17 \%$ of the transgenic K-326. It is not clear why some of the transgenic K-326 plants developed symptoms of TSWV infection, but this may explain the unexpected lower yield compared with the ASM + IMDtreated transplants.

In greenhouse experiments with TSWV and tobacco (9) and other systems, host age had a pronounced effect on plant susceptibility $(7,18)$. Mandal (9) found that 14-week-old tobacco plants had fewer local infections and significantly fewer systemic infections when mechanically inoculated in the greenhouse than the 6- or 10 -week-old tobacco plants. In the present study of natural TSWV epidemics in the field, a significant effect of transplant age on systemic TSWV infection was noted in only one of five trials and a significant effect of transplant age on the percentage of symptomatic plants was observed in two of five trials. However, a trend toward reduced infection and symptom development with increased transplant age was observed in most trials (data not shown). A similar trend of increased yield with increased transplant age was also observed in most of the trials (data not shown), although the differences were statistically significant only in the 2006 trial. The influence of transplant age on infection, symptom development, and yield was most pronounced for transplants not treated with ASM and IMD. In these trials, 6-WOT would be considered young, 8-WOT would be considered medium aged, and 10-WOT would be considered old. In order to produce the older transplants, seedlings were clipped four to five times to reduce excessive foliage. The physical damage produced by the clipping procedure may induce an SAR reaction. The 6-WOT were clipped at least once and it would be expected that an SAR reaction would be induced in these transplants as well. We can only speculate that any SAR induction might have been influenced by the number of times the plants were clipped. This may explain why, in the 2003 trials (early and late), the yield of nontreated 10-WOT (NC-71) was higher than nontreated 6WOT (NC-71 and K-326) and was similar

Table 4. Effects of tobacco cultivar on incidence of Tomato spotted wilt virus and yield in the 2003 (late planting) and 2004 trials $^{\mathrm{w}}$

\begin{tabular}{lcccl}
\hline Trial, cultivar & $\begin{array}{c}\text { Symptomatic } \\
\text { plants (\%) }\end{array}$ & AUDPC $^{\mathbf{x}}$ & $\begin{array}{c}\text { Systemic } \\
\text { infection }(\%)^{\mathbf{y}}\end{array}$ & $\begin{array}{c}\text { Yield (kg/ha } \\
\text { dry weight) }\end{array}$ \\
\hline 2003 (late) & & & & \\
NC-71 & $21 \mathrm{a}$ & $738 \mathrm{a}$ & $35 \mathrm{a}$ & $2,882 \mathrm{a}$ \\
K-326 & $27 \mathrm{a}$ & $1,010 \mathrm{~b}$ & $29 \mathrm{~b}$ & $2,779 \mathrm{a}(3,667)$ \\
2004 & & & & \\
NC-71 & $49 \mathrm{a}$ & $1,444 \mathrm{a}$ & $56 \mathrm{a}$ & $2,088 \mathrm{a}$ \\
K-326 & $64 \mathrm{~b}$ & $1,985 \mathrm{~b}$ & $70 \mathrm{~b}$ & $1,744 \mathrm{~b}(3,221)$ \\
\hline
\end{tabular}

${ }^{\text {w}}$ Values are means of five replications of two chemical treatments (acibenzolar- $S$-methyl + imidacloprid [ASM + IMD] and nontreated) and two transplants ages (6-week-old transplants [6-WOT] and 10 -WOT). Means within a column and year followed by the same letter were not significantly different $(\alpha=0.05)$ based on $F$ tests in SAS PROC MIXED.

${ }^{x}$ AUDPC $=$ area under the disease progress curve, based on weekly assessments of percentage symptomatic plants.

${ }^{y}$ Systemic infection was determined by enzyme-linked immunosorbent assay. Values are means of percentages of positives based on root samples of 10 randomly selected plants per plot for each of the five replications of two chemical treatments (ASM + IMD and nontreated) and two transplants ages (6-WOT and 10-WOT).

${ }^{z}$ Values in parentheses are mean yields for the nonsusceptible transgenic K-326.

Table 5. Effects of age of tobacco transplants on development of Tomato spotted wilt virus in the 2006 trialy $^{\mathrm{y}}$

\begin{tabular}{lccc}
\hline $\begin{array}{l}\text { Transplant age } \\
\text { (weeks) }\end{array}$ & $\begin{array}{c}\text { Symptomatic plants } \\
(\boldsymbol{\%})\end{array}$ & AUDPC $^{\mathbf{z}}$ & $\begin{array}{c}\text { Yield } \\
(\mathbf{k g} / \text { ha dry weight) }\end{array}$ \\
\hline 6 & $37 \mathrm{a}$ & $904 \mathrm{a}$ & $2,755 \mathrm{a}$ \\
10 & $30 \mathrm{~b}$ & $651 \mathrm{~b}$ & $2,981 \mathrm{~b}$ \\
\hline
\end{tabular}

y Values are means of five replications of two cultivars (NC-71 and K-326) and two chemical treatments (acibenzolar- $S$-methyl + imidacloprid and nontreated). Means within a column followed by the same letter were not significantly different $(\alpha=0.05)$ based on $F$ tests in SAS PROC MIXED.

${ }^{\mathrm{z}}$ AUDPC $=$ area under the disease progress curve, based on weekly assessments of percentage symptomatic plants. 
may be quite high for the minimal investment required.

The combination of ASM and IMD, in general, decreased infection and increased yield over the nontreated plants. Although there was no effect of transplant age on incidence of TSWV when combined with greenhouse treatments, the potential advantage of reduced phytotoxicity from greenhouse applications of ASM seen with older transplants may be a benefit to growers. The effect of treatment with ASM and IMD and transplant age on the incidence of TSWV symptomatic plants varied among years and could be due to varying disease pressure and environmental conditions during the time the transplants were most susceptible.

As observed in these trials and other studies, many factors influence the incidence of TSWV in flue-cured tobacco in any given year $(4,6,11,12)$. To be able to compare yields within a year, we included a transgenic K-326 that is not susceptible to TSWV but would be affected by weather and other factors during the growing season. The incidence of TSWV on the Bowen Farm varies depending on the location on the farm. The trials were not located in the same areas on the farm over the years, which could have affected the incidence of TSWV. IMD affects the settling and probing behavior of thrips. The tobacco thrips ( $F$. fusca), the most important thrips species in tobacco in Georgia, probed for a significantly shorter time on IMD-treated tomato leaves than on nontreated tomato leaves (6). This behavior may also occur on other solanaceous hosts such as tobacco. The shorter time thrips spend probing on IMD-treated transplants could result in fewer infections with TSWV. Rainfall and minimum and maximum temperatures during the growing season did not correlate with the inci- dence of TSWV (data not shown). The age of transplants had a significant effect on the incidence of TSWV-infected or symptomatic plants only in some years. However, numerical trends observed in most of the trials suggest that transplant age may influence infection, disease development, and yield. Given the very few tools we have available to manage this disease, the use of older tobacco transplants should be considered as part of a TSWV management program.

\section{LITERATURE CITED}

1. Anonymous. 2002. Georgia Tobacco Growers' Guide. G. M. Moore, ed. Univ. Ga. Coop. Ext. Serv. Publ. CSS 98-9, Tifton, GA.

2. Chinnasri, B., Sipes, B. S., and Schmitt, D. P. 2006. Effects of inducers of systemic acquired resistance on reproduction of Meloidogyne javanica and Rotylenchulus reniformis in pineapple. J. Nematol. 38:319-325.

3. Csinos, A. S. 1986. Evaluation of timing application of metalaxyl for tobacco black shank. Appl. Agric. Res. 1:120-123.

4. Csinos, A. S., Pappu, H. R., McPherson, R. M., and Stephenson, M. G. 2001. Management of Tomato spotted wilt virus in flue-cured tobacco with acibenzolar- $S$-methyl and imidacloprid. Plant Dis. 85:292-296.

5. Friedrich, L., Lawton, K., Ruess, W., Masner, P., Specker, N., Gut Rella, M., Maier, B., Dincher, S., Staub, T., Uknes, S., Métraux, J.P., Kessmann, H., and Ryals, J. 1996. A benzothiazole derivative induces systemic acquired resistance in tobacco. Plant J. 10:61-70.

6. Joost, P. H., and Riley, D. G. 2005. Imidacloprid effects probing and settling behavior of Frankliniella fusca and Frankliniella occidentalis (Thysanoptera: Thripidae) in tomato. J. Econ. Entomol. 98:1622-1629.

7. Lapidot, M. 2002. Screening common bean (Phaseolus vulgaris) for resistance to Tomato yellow leaf curl virus. Plant Dis. 86:429-432.

8. Lawton, K. A., Friedrich, L., Hunt, M., Weymann, K., Delaney, T., Kessmann, H., Staub, T., and Ryals, J. 1996. Benzothiadiazole induces disease resistance in Arabidopsis by activation of the systemic acquired resistance signal transduction pathway. Plant J. 10:7182.
9. Mandal, B., Wells, M. L., Martinez-Ochoa, N., Csinos, A. S., and Pappu, H. R. 2007. Symptom development and distribution of Tomato spotted wilt virus in flue-cured tobacco. Ann. Appl. Biol. 151:67-75.

10. Matheron, M. E., and Porchas, M. 2002. Suppression of Phytophthora root and crown rot on pepper plants treated with acibenzolar- $S$ methyl. Plant Dis. 86:292-297.

11. McPherson, R. M., Stephenson, M. G., Lahue, S. S., and Mullis, S. W. 2005. Impact of earlyseason thrips management on reducing the risks of spotted wilt virus and suppressing aphid populations in flue-cured tobacco. $\mathrm{J}$. Econ. Entomol. 98:129-134.

12. Momol, M. T., Olson, S. M., Funderburk, J. E., Stavisky, J., and Marois, J. J. 2004. Integrated management of Tomato spotted wilt on fieldgrown tomatoes. Plant Dis. 88:882-890.

13. Nauen, R. 1995. Behavior modifying effects of low systemic concentrations of imidacloprid on Myzus persicae with special reference to an antifeeding response. Pestic. Sci. 44:145-153.

14. Pappu, H. R., Csinos, A. S., McPherson, R M., Jones, D. C., and Stephenson, M. C. 2000 Effect of acibenzolar-S-methyl and imidacloprid on suppression of tomato spotted wilt tospovirus in flue-cured tobacco. Crop Prot. 19:349-354.

15. Oostendorp, M., Kunz, W., Dietrich, B., and Staub, T. 2001. Induced disease resistance in plants by chemicals. Eur. J. Plant Pathol. 107:19-28.

16. Romero, A. M., Kousik, C. S., and Ritchie, D. F. 2001. Resistance to bacterial spot in bell pepper induced by acibenzolar- $S$-methyl. Plant Dis. 85:189-194.

17. Ryals, J. A., Neuenschwander, U. H., Willits, M. G., Molina, A., Steiner, H.-Y., and Hunt, M. 1996. Systemic acquired resistance. Plant Cell 8:1809-1819.

18. Stoeva, P., Yankulova, M., Nikolaeva, V., Bachvarova, R., Ivanova, L., Maiss, E., Adam, G., Vulkov, V., Guelemerov, S., and Atanassov, A. 1998. Long-term resistance to tomato spotted wilt virus in transgenic tobacco cultivars expressing the viral nucleoprotein gene: greenhouse and field tests. Mol. Breed. 4:155164.

19. Wintermantel, W. M., and Kaffka, S. R. 2006. Sugar beet performance with curly top is related to virus accumulation and age at infection. Plant Dis. 90:657-662. 